\title{
The construction of permanent education in the process of health work in the state of Minas Gerais, Brazil
}

A construção da educação permanente no processo de trabalho em saúde no estado de Minas Gerais, Brasil La construcción de la educación permanente en el proceso de trabajo en salud en Minas Gerais, Brasil

\author{
Kênia Lara Silva ${ }^{1}$ \\ Juliana Alves Viana Matos ${ }^{1}$ \\ Bruna Dias França ${ }^{1}$
}

1. Universidade Federal de Minas Gerais. Belo Horizonte, MG. Brazil.
Corresponding author:

Kênia Lara Silva.

E-mail: kenialara17@gmail.com

Submitted on 03/19/2017.

Accepted on 05/21/2017.

DOI: 10.1590/2177-9465-EAN-2017-0060

\begin{abstract}
Objective: To analyze the practices of Educação Permanente em Saúde (EPS - Permanent Education in Health) and its repercussions on the work process of the involved actors. Method: This is a qualitative study, developed in two phases: mapping of EPS experiments in Minas Gerais and visits and interviews with nine managers, 22 coordinators and 18 professionals from ten selected municipalities. The first phase occurred from March to October 2014 and the second from March to June 2015 The material was analyzed under the prism of Critical Discourse Analysis. Results: The denomination of educational actions as training still prevails among professionals, contrary to national politics. However, it was possible to identify EPS signs in the professionals' daily life, indicating changes in the work process. Conclusion: There is evidence of a process of transformation of educational practices mobilized by EPS, despite the hegemonic model of education in the field of health work. Implications for practice: This is the need to problematize the daily work process in health.
\end{abstract}

Keywords: Continuing Education; Public Policies; Workers; Unified Health System.

\section{Resumo}

Objetivo: Analisar as práticas de educação permanente em saúde (EPS) e as suas repercussões no processo de trabalho dos atores envolvidos. Método: Estudo qualitativo, desenvolvido em duas fases: mapeamento das experiências de EPS em Minas Gerais e visitas e entrevistas com nove gestores, 22 coordenadores e 18 profissionais de dez municípios selecionados. A primeira fase ocorreu de março a outubro de 2014 e a segunda de março a junho de 2015 . O material foi analisado sob o prisma da Análise Crítica do Discurso. Resultados: Denominação de ações educativas como treinamento ainda impera entre profissionais, perspectiva contrária à política nacional. Porém, foi possível identificar sinais de EPS no cotidiano dos profissionais, indicando mudanças no processo de trabalho. Conclusão: Há indícios de um processo de transformação das práticas educativas mobilizados pela EPS, apesar do modelo hegemônico de educação no campo do trabalho em saúde. Implicações para prática: Necessidade de problematizar o cotidiano do processo de trabalho em saúde.

Palavras-chave: Educação Continuada; Políticas públicas; Trabalhadores; Sistema Único de Saúde.

\section{Resumen}

Objetivo: Analizar las prácticas de Educación Permanente en Salud (EPS) y sus repercusiones en el proceso de trabajo de Ios actores relacionados. Método: Estudio cualitativo, desarrollado en dos fases: mapeo de las experiencias de EPS en Minas Gerais; y visitas y entrevistas con nueve gestores, 22 coordinadores y 18 profesionales de diez municipios seleccionados. La primera fase ocurrió entre marzo y octubre de 2014, la segunda, entre marzo y junio de 2015. Se utilizó el Análisis Crítico del Discurso. Resultados: La denominación de acciones educativas, como entrenamiento, es imperativa todavía, una perspectiva contraria a la política nacional. Entretanto, fue posible identificar señales de EPS en el cotidiano de los profesionales. Conclusión: Existen indicios de un proceso de transformación de las prácticas educativas, a pesar del modelo hegemónico de educación en el campo de la salud. Implicaciones para la práctica: Necesidad de problematizar el cotidiano del proceso de trabajo en salud.

Palabras clave: Educación Continuada; Políticas Públicas; Trabajadores; Sistema Único de Salud. 


\section{INTRODUCTION}

Historically, the training of health professionals has been delineated by a model of health care based on positivist science, centered on conservative and inconsistent methodologies with the health problems of the population. In this understanding, knowledge is fragmented and reduced to the quest for technical efficiency, reducing its potential for integrated care. ${ }^{1}$ This paradigm is put in check and the need for other models to guide the training process and, consequently, professional practices, is observed.

Globally, the health workforce is recognized as a pillar for the strengthening of health services, capable of ensuring greater access to health and good quality services. ${ }^{2}$ However, only an increase in the number of professionals is not enough, it is necessary to ensure that these professionals are able to meet the demands and needs of each population. In this sense, the World Health Organization signals the importance in terms of continuing education and training for health professionals. ${ }^{3}$ This process should be in line with services, in addition to the training of educational professionals, as well as the use of effective methods and access to appropriate infrastructures, equipment and tools. ${ }^{3,4}$

In China, for example, health reforms have been in place since the 1990s, encouraging the training and hiring of nurses, strengthening primary health care, and continuing education for health professionals. ${ }^{5}$ Despite these efforts, the world's most populous country needs improvements in its complex system of education for professionals, including greater participation of public and private training institutions and government. ${ }^{5}$

The ease of access to literature has contributed to the dissemination of new information and training programs, and in the United States the Centers for Disease Control and Prevention (CDC) has been responsible for promoting the introduction of new health topics in universities. ${ }^{4}$ Updating information makes it easier for health professionals to be aware of knowledge and skills, consistent with the dynamism of global change. ${ }^{6}$

Given this scenario, the importance of the acquisition of new knowledge by health professionals is recognized. However, these changes must be adapted to the needs of individuals and populations. In the Brazilian context, the creation of the Sistema Único de Saúde (SUS - Unified Health System) points to the debate on changes in health education and performance, demanding qualified professionals to approach the health-disease process in an expanded and humanistic way. ${ }^{1}$ With this, new policies in the field of education and its interface with health have been implemented. These include the Política Nacional de Educação Permanente em Saúde (PNEPS - National Policy on Permanent Education in Health), instituted in 2004 through Ordinance No. 198/2004, which established guidelines for its implementation. In 2007, it was reformulated by Administrative Rule no. 1996/2006, to adapt it to operational guidelines and the Health Pact. ${ }^{7}$ Thus, Educação Permanente em Saúde (EPS - Permanent Health Education) emerges as a strategy of the Ministry of Health for the development of health professionals and to strengthen the SUS.

It is a pedagogical concept aimed at favoring the relationship between teaching and service, as well as strengthening teaching and health care, acting in the axes of formation, management, development and social control. ${ }^{7}$ In this process, workers are perceived as everyday protagonists in the health services, changing contexts, and constructing and deconstructing saberes. ${ }^{8}$

There are distinctions between continuing education (CE) and EPS. The scientific literature indicates that in the CE process, the updating of specific knowledge is the main objective, while in the EPS it is the transformation of the health processes that must guide the way of thinking and making the educational processes in the health services..$^{9,10}$ In this direction, EPS is taken as a device for problematizing the work process, starting from an existing situation in search of changing, transforming and overcoming it. ${ }^{11}$

The analysis of this object demands to consider that the problematization of daily life implies a change in the relations of power. Thus, the problematization movement must involve the constant questioning of the subject about his work process. ${ }^{12}$ However, for this to occur, it is necessary that health actions be carried out according to the health needs of the populations, which requires that managers, workers and users are integrated into the health work of everyday life, with the possibility of critical exercise of their freedoms. From this, arises the following question: how did the implementation of EPS strategy contribute to the health work process in the state of Minas Gerais?

It is understood that it is necessary to know how the EPS has been happening in the work process in health, considering that its political implementation completed more than ten years. In this sense, the main objective of this paper is to analyze EPS practices and their repercussions on the work process of the actors involved.

\section{METHODS}

This study presents the results of the research Permanent education in health and the ways of thinking and doing management, attention, formation and participation in and for SUS. This is a qualitative article anchored in the methodological theoretical framework of Critical Discourse Analysis proposed by Fairclough. ${ }^{13}$

The methodological course was developed in two phases. Firstly, the EPS experiments carried out in Minas Gerais were mapped through an electronic questionnaire sent to the Secretarias Municipais de Saúde (SMS - Municipal Health Departments) of the 853 municipalities of the state, between 
March and October 2014, addressed to the municipal secretary or representative appointed by him. For that, a questionnaire was created and made available via the web in the domain 'educacaopermanentesaude.com.br'. The instrument contained open and closed questions, requesting information about educational practices identified as EPS, carried out in the last five years, regardless of the type of health service. The questions included the description, the objectives, the source used to finance the practice, the level of attention contemplated, which motivated the development of the practice, the target audience and the current situation of informed practice. This set of information was called EPS Practice informed by the municipality.

From the 853 SMS of the state of Minas Gerais, we obtained answers from 492. From the analysis of the data obtained by the questionnaire, the second stage of the survey was started, for which municipalities were selected for in-depth analysis. The guidelines of the PNEPS were taken as guidance, namely: the concept of permanent education in health and its relation to work and to the practices of training and professional development; ${ }^{7: 20}$ and the relationship of the regional management collegiate with the teaching-service integration commissions for the SUS, which guides the construction and implementation of actions and interventions in the area of health education in response to the needs of the service. With these guidelines, the following criteria for inclusion of municipalities for the second phase were defined: practices still in progress; using participatory methodologies and counting on the participation of at least two distinct professional categories to characterize multi-professionality, one of which must be nursing; representation of a municipality in each of the ten macro-regions of the state of Minas Gerais. Ten municipalities met the criteria and composed the final scenario of the study.

Data collection from the second phase was carried out from March to June 2015. Fieldwork involved visits that generated observation and interviews. After the signing of the informed consent, 49 interviews were conducted and recorded with: nine managers, 22 coordinators and 18 professionals linked to the EPS practices indicated. The average duration was 25 minutes, totaling 12 hours and 54 minutes of recording. A semi-structured script was used containing the following questions: How was the EPS practice planned in the municipality? How is EPS funded? What are the repercussions of EPS practices on the work process?

Among the nine managers interviewed, three (33.3\%) were male and six (66.7\%) were female. Two nurses, two dentists, an administrator, a social worker, a pedagogue, a merchant and a psychologist were involved in the training/occupation. Of the 22 coordinators, five (22.8\%) were male and $17(77.2 \%)$ were female; as to the training: 15 nurses, two physiotherapists, two occupational therapists, two dentists and one nutritionist. Among the 18 professionals interviewed, three (16.7\%) were male and 15 (83.3\%) were female; in total, five nurses, two doctors, two nursing technicians, one agente comunitário de saúde (ACS - community health agent), a physical educator, a health aide, a physiotherapist, a nutritionist, an arts teacher, a psychologist, an education secretary, and an oral health technician.

To ensure privacy and confidentiality regarding the information and statements provided, the names of the municipalities and the interviewees were replaced by codes. The letter $M$ followed by numbers was used for municipalities, the letters $G$ for gestor (manager), $\mathrm{C}$ for coordinator and $\mathrm{P}$ for professional, followed by random sequential numbering. Thus, the first professional of the municipality one was identified as M1P1 and so on.

It is emphasized that on-site interviews are an important source of data that allow an analysis of the interviewees' discourses, rescuing social discursive conventions and norms. Critical analysis is adequate for understanding social problems and it seeks to articulate social and linguistic perspectives, reaching understanding in terms of the social sphere..$^{14}$ In it, discourse is used to report the use of language as part of social practice, a mode of action and representation, socially and historically situated, in a dialectical relationship with the social structure. ${ }^{13}$

The study followed the requirements of Resolution 466/2012 of the National Health Council and is registered in the Research Ethics Committee of the Federal University of Minas Gerais under CAAE 22830813.5.0000.5149.

\section{RESULTS AND DISCUSSION}

From the analysis of the discourses, two categories were revealed. In the first, permanent education in health: words and concepts in the speeches of social actors; the words and concepts that make up the discourse on EPS in the municipalities were highlighted, revealing a diversity of terms to denominate existing practices, sometimes guided by different conceptions. And in the second, permanent education in health: the possibility of changing the work process in health; the influence of different EPS practices on the work process was pointed out, revealing that the basis of this process is problematization.

\section{Permanent education in health: words and concepts in the speeches of social actors}

The interviews analyzed revealed common points, especially regarding the ways to lexicalize EPS. The lexicalization or significance of the world demarcates a time and an era because it is related to the relations between different groups of people and are important elements for understanding social actors and their relation to social practice. ${ }^{13}$

In this sense, when asked about EPS in health, participants use terms such as capacity building, training and recycling to refer to the educational actions developed in the municipality. This finding portrays a historical-social process that presents the multiplicity of concepts and conceptions as its own characteristic. 
[...] I think this is the main motivation I feel during training, which contributes a lot to the professional, especially when it is getting further away, right, of the training year. We get outdated and the capabilities help us to update, right? (M8P3)

[...] because perhaps this way we could really make the EP schedule fulfilled in its entirety, but unfortunately for lack of resources, we need to be trained. We need it because, since we are promoters of this, we also need to be recycled. (M3C1)

[...] so, permanent education comes when you need it, a course, a training, etc. It is not a situation that is already entrenched; It is a common practice; this issue of having the student and the preceptor within the unit; [...] and courses in medicine, nursing, and multi-professional residency. So I think this greatly stimulates professionals who are there and it opens this vision, opens this field of vision of professionals for the necessity of practice, so that education continues to be permanent, not occasional. (M6G1)

Capacities are intentional and programmed actions and their central objective is to strengthen knowledge, skills, attitudes and practices. ${ }^{15}$ The need for elaboration of ongoing training programs for health professionals is recommended, especially for the development of differentiated work. ${ }^{16}$

Analyzing the historical construction, it is possible to perceive that the training is part of the history of EPS. The proposals made by the Pan American Health Organization in the 1980 s brought into the heart the idea of developing in-service training, ${ }^{17}$ such as Family Health Capacity Building and Training, since they were programs that carried the terminology in their names. ${ }^{18,19}$ In addition, training was understood as an ally of education, insofar as it provided the necessary knowledge to professional life. ${ }^{17,20}$

In the political field, in recent years, there has been a suppression of the training of official texts. Few are the term citations in the PNPES, which did not happen in the discourse spoken by the participants of this study. The discourse is dialectically connected to other elements of social life, which indicates the need to consider language when analyzing social events..$^{13}$ Thus, a distinction is made between the political discourse and the discourse of those who operate EPS in daily health services.

It can be seen that the incentive to training has lasted for so many years that it is connected to the structural level and not only in the particular context of the EPS, in which qualification means, for the professional, to qualify, to be qualified for the service. EPS is closely related to job training. However, at present, the discussions regarding this object criticize the use of the training, reducing it to a simplified process, with instrumental vision about education and that operates by the logic of programs with beginning and end. ${ }^{15}$

The participants of this study indicate the training as a possibility of acquiring the immediate knowledge necessary for the professional performance. The participant $\mathrm{M} 3 \mathrm{C} 1$ uses the word recycled to refer to this demand, a term that refers to the demands of the capitalist mode of production, in which labor must be increasingly rapid and massified. ${ }^{21}$

It is recognized that training activities are still an important form of education applied to work. ${ }^{19}$ However, the strong presence of this term in discourses denotes an indiscriminate use, despite the attempt to overcome it in educational health processes. It is evidenced that its quotation occurs even when referring to actions developed in the daily life of health teams that have problematizing and continuous character.

When analyzing the workers' testimony in terms of their participation in the actions, it was possible to show that the practices are referenced by them as a space of exchange and an updating device. In this sense, the term training is used to identify the EPS strategy offered by the municipalities.

Regarding the NASF, sometimes there is also a moment of permanent education outside the meeting, on demand or not... let me think of an example, we have a food and nutrition surveillance system, then we had a training with the ACS or with the staff that will do the typing at the end of the year, and now at the beginning of this year the anthropometric training, that is, measure in order to level knowledge. (M8C1)

The professionals too; we have also been close to doing all this training with them, so that they can give support to the employees, that is, the employees arrive and they know how to tell them what the conduct is, what is to be done; a training that first had to be done with the team and that is done until today with the whole team, and so a team does it... training with the units, with the unit team and another team also does it with the community, with the general population. (M5G1)

The interviewees express that the training is encouraged and happens sporadically, with specific themes, so that it can be later replicated among the other team members. In the speeches, training is the example of EPS action and it acts in the perspective of leveling and updating knowledge. Current discussions question training, mainly because of the conceptual confusion surrounding those who mistakenly regard training as synonymous with EPS: 
The action of Permanent Education in Health is not about capacity building or training, but about constructing knowledge in a horizontal, intersectoral and interdisciplinary relationship. It prioritizes the teaching-learning relationship driven by the critical debate and discussions of the demands present in the daily life of health services, which means that the starting point are the problems or problematization of the concrete reality. ${ }^{22: 509}$

The denomination of strategies of educational actions as training still reigns among professionals. This perspective contradicts the present perspective in the PNEPS and shows that the conceptual conception that prevails in the services is still of $C E$.

It must be understood that this fact does not constitute a problem. There are times when building capacity and training are necessary, when, for example, a new vaccine is launched and inserted in the national vaccination calendar and professionals need to be trained for this new procedure, since they must acquire, among others, knowledge about technique and its indication.

However, it is noteworthy that in these processes there is the possibility of problematizing and reflecting critically on the health work process. Even at times entitled as capacity building or training, professionals have institutional, formal and systematized opportunities to exchange experiences with colleagues and problematize everyday life. In constructing this rationalization, EPS expresses itself, emerging in different moments and spaces of the work process, including capacitation and training.

In this work, there is no intention to classify the actions indicated by the municipalities as EPS or CE, in a derogatory perspective. On the contrary, it seeks recognition of the practices developed and its transformative potential. The rescue of themes related to the daily life of the teams, even through courses, capacitation or training, has enabled professionals to problematize health work, regardless of the nomenclature used.

In this direction, the findings reveal that EPS starts from the doubts that arise in the work process and that are clarified by other professionals, revealing the construction of new relationships that allow the transformation in and for work, directly influencing the quality of health services.

The discussion of real cases/concepts among the workers of the Núcleo de Apoio à Saúde da Família (NASF - Family Health Support Center) and the Centro de Atenção Psicossocial (CAPS - Psychosocial Care Center) of the municipalities appears as an innovation in the EPS. There is a new possibility that exists in the relationship between NASF teams and the Estratégia Saúde da Família (ESF - Family Health Strategy) teams, as an EPS device.
[...] We also learned about matricity, because until then, there was the NASF in the cities... the CAPS, but we had no information; so at the time no meeting was held as the meetings being held now to talk about it. So we learned that in cases that existed in the unit, we... any of us, that is, the technician, the nurse or the doctor, could be holding a meeting to discuss that patient's case. (M3P3)

'You are not going to teach only your specialties, you are going to teach the management.' [...] I have to learn to pass on to them. 'Continuing education happens to you, but you share it with the teams. '[...] NASF training takes place in several meetings. On the scheduled NASF agenda, every Wednesday afternoon there is a meeting and we set a day of the month so we can make the changes, and sometimes it's more than once a month. (M2C1)

With regard to the NASF, sometimes there is a moment of permanent education outside the meeting, on demand or not as well... (M4C1)

For some interviewees, it was evidenced that the matrixbased strategy is a facilitator for the development of EPS actions within the scope of the service. Through this mechanism, professionals have the opportunity to discuss cases and jointly build proposals to support therapeutic plans. $\mathrm{M} 2 \mathrm{C} 1$ relies on the speech of his team, revealing the incorporation of multiple texts in the interviewees' speech, known as intertextuality. The intertexts indicate the replication and consolidation of certain discourses. In the case under analysis, one can notice the strengthening of the discourse of multi-professionality and interdisciplinarity present in the EPS practices.

The adoption of strategies that allow the participation of the subject and the exchange of experiences between the team favors EPS. ${ }^{17,5}$ From the analysis of the difficulties in the collective, critical nodes are identified and the confrontation is discussed, enabling the construction of contextualized strategies that include all professionals connected to the health service. ${ }^{9}$ Educational actions are an odd moment to reflect on the work process and to think/propose changes that qualify the care provided.

\section{Permanent education in health: possibility of changing the process in health work}

The findings allow us to identify that the participants recognize the repercussions of the EPS in the work process of the team and point to indicative changes in the workers' social practice. The speeches indicate that the EPS constructs and 
reconstructs exchanging spaces between professionals, which contributes to the qualification of the work and, consequently, of the assistance.

[...] mainly for the population, for patients. [...] I think that once the doctor is more prepared to help the team, the patient gets much better accompanied. (M4P1)

[...] We learn a lot... a lot of things with other professionals. [...] the repercussion is very positive, we gain a lot in terms of knowledge. We are bringing improvements not only for us, professionals, but also for the community. (M9P1)

[...]l sit down with the team and we share whatever the team thinks needs to be improved [...]. (M4P2)

EPS is in a dialectical movement, surrounded by contradictions, but at the same time it invokes a new line of thinking in terms of health. This perspective removes professionals from the role of subjects and places them as protagonists in the teaching-learning process, an important device of EPS. ${ }^{18,15}$ Thus, we see the production of changes in the health field, which presupposes that the old forms of practicing health education were insufficient to promote reflections about the work process on a permanent basis.

EPS, in its different forms, is presented by the interviewees as a potentiator of a new way of operating health work.

When you have the knowledge and you understand that something new has come up, and you know about it, with greater emphasis, my confidence, as a professional is bigger, you know, and this is what we pass on to the team, that we pass on to patients. (M4P2)

\section{[...] The population believes more in the professional who is qualified. (M8P2)}

It's great because it's like I told you before, you bond with the patient and when you pay a visit and the patient makes a complaint, then you can have conviction of what you are passing on to the patient. (M3P2)

[...] The idea is to try to heal their problem; if it is not possible, at least lessen that problem, right, that is afflicting them. Through these practices of permanent education we can prepare ourselves to achieve this goal that is the satisfaction of the patient, you know, and that is what motivates me... to be able to enable myself and to be able to help those I can help from my team, To help patients more significantly.(M1C1)

In the reports, the professionals who participate in the actions refer to the trust acquired both for the professional who feels safe to provide assistance, and for the user who believes and trusts this skilled professional. Quality improvement appears both in the production of care and in the improvement of quality indicators. From the managerial point of view, this improvement translates as a reduction in referrals to specialized services and hospitalization, increasing the service's resoluteness. ${ }^{23}$

By realizing the benefits of EPS for the population, professionals have the opportunity to improve health practice. It is related to the insertion of problematization in everyday life. It is evidenced that professionals develop a keener listening, capable of understanding the issues brought by users and establish more effective communication with them. At that moment, the user also becomes protagonist, giving the professional the contact with the social practice. It regards the understanding that EPS is not restricted to specific moments or isolated lectures given by specialists; it encourages a process of change in health work, with openness for greater social participation.

The PNEPS itself emphasizes the need for the worker to participate in these educational practices, whether in the form of lectures, courses or other events of this nature, whose purpose is to train health professionals, as well as instrumentalize them to face the problems of their daily life at work. ${ }^{24}$

We acknowledge the advances of EPS, despite the permanence of denominations used to characterize educational actions in health services. The findings contribute to the critical reflection on the organization of the work process and the emerging need to problematize the day to day, with the possibility of identifying the powers of the workers and users for new educational practices in health and for the strengthening of EPS. Emphasis is given to the importance of continuous incentive to these actions that directly impact the care provided. Analyzing how these practices are developed provides support for the understanding of the teaching-learning process in health services.

It is possible to observe the nursing relationship to EPS practices, related mainly to the contingent of professionals of this category in the health services. There is evidence of an improvement in the quality of care provided to the user, based on EPS practices developed for nurses and nursing technicians.

\section{FINAL CONSIDERATIONS}

Despite the challenges from a conceptual point of view and conceptions, EPS in the municipalities emerges as the problematization of daily life in the face of the professionals' questions or the daily challenges faced by the teams from which they raise themes for discussion.

To continue building, the strategic importance of EPS is recognized to empower/strengthen workers and users for new practices of assistance, teaching, management and social participation. The results allow inferring that even using denominations such as capacity building and training, there is a conception of EPS under construction in the daily life of 
health workers, because, despite the conceptual, political and methodological ignorance, EPS happens in the day to day of these workers. It was evidenced the absence of the user as participant of the EPS processes.

The study contributes to the scientific technical production of EPS, but the findings should not be generalized. The need to deepen the reflections between workers and users in each municipality is pointed out in order to expand the concepts of problem-making education and the use of active methodologies in the EPS processes as a device for reflection and reconstruction of assistance, teaching, management and Social participation.

It is understood that the limitations of the study refer to its state restriction, which prevented a national view of the subject. It is suggested that more research be done on this subject, making it possible to know the dynamicity that involves the accomplishment of educational activities in the SUS context.

\section{ACKNOWLEDGEMENTS}

Thanks to the National Council for Scientific and Technological Development, the Foundation for Research Support of the State of Minas Gerais and Pro-Rectory of Research of the Federal University of Minas Gerais for the financial assistance and grant of scholarships.

In memoriam of UFMG emeritus teacher Roseni Rosângela de Sena, who contributed to the preparation of the manuscript.

\section{REFERENCES}

1. Gigante RL, Campos GWS. Política de formação e educação permanente em saúde no brasil: bases legais e referências teóricas. Rev Trab Educ Saúde [Internet]. 2016 Nov; [cited 2017 Mar 5]; 14(3):747-63. Available from: http://www.scielo.br/scielo.php?script=sci_arttext\&pid=S198177462016000300747\&lng=en\&nrm=iso. DOI: 10.1590/1981-7746sip00124

2. Zodpey S, Sharma A. Advancing reforms agenda for health professionals' education through transformative learning. Indian J Public Health [serial online]. 2014; [cited 2017 Apr 24]; 58(4):219-23. Available from: http:// www.ijph.in/text.asp?2014/58/4/219/146274

3. World Health Organization. Transforming and scaling up health professionals' education and training. Geneva: World Health Organization; 2013. [cited 2017 Apr 24] 124 p. Available from: http:// whoeducationguidelines.org./sites/default/files/uploads/WHO_ EduGuidelines_20131202_web.pdf

4. Evashwick CJ, Tao D, Bax K. Analysis of the literature pertaining to the education of public health professionals. Front Public Health [Internet]. 2013; [cited 2017 Apr 24]; 1:47. Available from: https://www. ncbi.nlm.nih.gov/pmc/articles/PMC3859983/citedby/. DOI: 10.3389/ fpubh.2013.00047

5. Hou J, Michaud C, Li Z, Dong Z, Sun B, Zhang J, et al. Transformation of the education of health professionals in China: progress and challenges. Lancet [Internet]. 2014; [cited 2017 Apr 24]; 384(9945):819-27. Available from: http://www.thelancet.com/journals/lancet/article/PIIS01406736(14)61307-6/supplemental.DOI: 10.1016/S0140-6736(14)61307-6

6. Frenk J, Chen L, Bhutta ZA, Cohen J, Crisp N, Evans T, et al. Health professionals for a new century: transforming education to strengthen health systems in an interdependent world. Lancet [Internet]. 2010; [cited 2017 Apr 24]; 376(9756):1923-58. Available from: http://www. thelancet.com/journals/lancet/article/PIIS0140-6736(10)61854-5/ fulltext?_eventld=login. DOI: 10.1016/S0140-6736(10)61854-5
7. Ministério da Saúde (BR). Portaria no 1.996, de 20 de agosto de 2007 (BR). Dispõe sobre as diretrizes para a implementação da Política Nacional de Educação Permanente em Saúde. Diário Oficial da União [Internet], Brasília (DF): Ministério da Saúde; 2007 [cited 2017 Mar 7] Available from: http://bvsms.saude.gov.br/bvs/saudelegis/gm/2007/ prt1996_20_08_2007.html

8. Franco TB, Chagas RC, Franco CM. Educação Permanente como prática. In: Pinto S, Franco TB, Magalhães MG, Mendonça PEX, Guidoreni AS, Cruz KT, et al, orgs. Tecendo Redes: os planos da educação, cuidado e gestão na construção do SUS. São Paulo (SP): Hucitec; 2012. p. 420-38.

9. Merhy EE, Feuerwerker LCM, Ceccim RB. Educación Permanente en Salud: una Estrategia para Intervenir en la Micropolítica de Trabajo en Salud. Salud Colectiva [Internet]. 2006 Aug; [cited 2017 Mar 10]; 2(2):147-60. Available from: http://www.scielo.org.ar/scielo. php?script=sci arttext\&pid=S1851-82652006000200004\&lng=es\&nr m=iso. http://dx.doi.org/10.1590/S1851-82652006000200004

10. Silva AN, Santos AMG, Cortez EA, Cordeiro BC. Limites e possibilidades do ensino à distância $(\mathrm{EaD})$ na educação permanente em saúde: revisão integrativa. Ciênc Saúde Coletiva [Internet]. 2015 dez; [cited 2017 Mar 10]; 20(4):1099-107. Available from: http://www.scielosp.org/scielo. php?script=sci_arttext\&pid=S1413-81232015000401099\&lng=pt\&nr $\mathrm{m}=$ iso. $h \mathrm{ttp}: / / \mathrm{dx}$.doi.org/10.1590/1413-81232015204.17832013

11. Haddad JQ, Roschke MA, Davini MC. Educación permanente de personal de salud. Washington: Organización Panamericana de la Salud; 1994. $247 \mathrm{p}$

12. Collar JM, Almeida Neto JB, Ferla AA. Educação permanente e o cuidado em saúde: ensaio sobre o trabalho como produção inventiva. Saúde em Redes [Internet]. 2016; [cited 2017 Apr 18]; 1(4):53-64 Available from: http://www.lume.ufrgs.br/handle/10183/140334. http:// dx.doi.org/10.18310/2446-4813.2015v1n4p53-64

13. Fairclough N. Analysing Discourse: Textual analysis for social research. London: Routledge; 2003. 270 p.

14. Magalhães I. Recontextualizações no discurso da estratégia de saúde da família. Cad Ling Soc. 2015; [cited 2017 Apr 22]; 16(2):17697. Available from: http://periodicos.unb.br/index.php/les/article/ view/15207

15. Davini MC. Enfoques, Problemas e Perspectivas na Educação Permanente dos Recursos Humanos de Saúde. In Brasil. Ministério da Saúde (MD). Secretaria de Gestão do Trabalho e da Educação na Saúde. Departamento de Gestão da Educação em Saúde. Política Nacional de Educação Permanente em Saúde [Internet]. Brasília (DF) Ministério da Saúde; 2009 [cited 2017 Mar 10]; p. 39-63. Available from: http://bvsms.saude.gov.br/bvs/publicacoes/politica_nacional_ educacao_permanente_saude.pdf

16. Roecker S, Marcon SS. Educação em saúde na estratégia saúde da família: o significado e a práxis dos enfermeiros. Esc Anna Nery [Internet]. $2011 \mathrm{dez}$; [cited 2017 Mar 10]; 15(4):701-9. Available from: http://www.scielo.br/scielo.php?script=sci arttext\&pid=S1414$81452011000400007 \&$ Ing=en\&nrm=iso. http://dx.doi.org/10.1590/ S1414-81452011000400007

17. Davini MC. Educación permanente en salud: serie PALTEX para Ejecutores de Programas de Salud. Washington: Organización Panamericana de la Salud; 1995.120 p.

18. Mishima SM, Aiub AC, Rigato AFG, Fortuna CM, Matumoto S, Ogata MN, et al. Managers' perspective on continuous health education in a region of São Paulo State. Rev Esc Enferm USP [Internet]. 2015 aug; [cited 2017 Mar 10]; 49(4):665-73. Available from: http://www.scielo.br/scielo.php?script=sci_arttext\&pid=S0080 62342015000400665\&lng=en\&nrm=iso. http://dx.doi.org/10.1590/ S0080-623420150000400018

19. Lima VV, Feuerwerker LCM, Padilha RQ, Gomes R, Hortale VA. Activators of processes of change: a proposal oriented to the transformation of educational practices and the training of health professionals. Ciênc Saúde Coletiva [Internet]. 2015 Jan; [cited 2017 Apr 22]; 20(1):279-88. Available from: http://www.scielo.br/scielo. php?script=sci_arttext\&pid=S1413-81232015000100279\&Ing=en http://dx.doi.org/10.1590/1413-81232014201.21992013 
20. Silva LAA, Leite MT, Pinno C. Contribuições das comissões de integração ensino-serviço na educação permanente em saúde. Trab Educ Saúde [Internet]. 2014 Aug; [cited 2017 Mar 10] 12(2):40324. Available from: http://www.scielo.br/scielo.php?script=sci arttext\&pid=S1981-77462014000200011\&Ing=en\&nrm=iso. http:// dx.doi.org/10.1590/S1981-77462014000200011

21. Sarreta FO, Eto F, Brentini DCS, Nogueira DO, Bisco GCB. Serviço social e educação permanente em saúde: a potencialidade para integração ensino-serviço. REFACS [internet]. 2016; [cited 2017 Apr 22]; 4(1):17-25. Available from: http://seer.uftm.edu.br/revistaeletronica/ index.php/refacs/article/view/1529. http://dx.doi.org/10.18554/refacs. v4i1.1529

22. Duarte MLC, Oliveira Al. Compreensão dos coordenadores de serviços de saúde sobre educação permanente. Cogitare Enferm [Internet].2012 set; [cited 2017 Mar 10]; 17(3):506-12. Available from: http://revistas. ufpr.br/cogitare/article/view/29292/19042.
23. Erdmann AL, Andrade SR, Mello ALSF, Drago LC. Secondary Health Care: best practices in the health services network. Rev Latinoam Enferm [Internet]. 2013 feb; [cited 2017 Mar 10]; 21(spe):1319. Available from: http://www.scielo.br/scielo.php?script=sci arttext\&pid=S0104-11692013000700017\&lng=en\&nrm=iso. http:// dx.doi.org/10.1590/S0104-11692013000700017

24. Cunha AZS, Rezende MS, Weigelt LD, Krug SBF, Feil Al. Implicações da educação permanente no processo de trabalho em saúde. Rev Espaço Saúde [Internet]. 2014 dez; [cited 2017 Mar 12]; 15(4):64-75. Available from: http://www.uel.br/revistas/uel/index. php/espacoparasaude/article/view/19911/pdf_48. http://dx.doi. org/10.22421/1517-7130.2014v15n4p64 